\title{
Van buite bekyk: Die teologie van die Nederduitsch Hervormde Kerk van Afrika tussen 1938 en 1950
}

\begin{tabular}{|c|c|}
\hline \multicolumn{2}{|l|}{$\begin{array}{l}\text { Author: } \\
\text { Dolf Britz }\end{array}$} \\
\hline $\begin{array}{l}\text { Affiliation: } \\
{ }^{1} \text { Department } \\
\text { History and } \mathrm{Cl} \\
\text { Faculty of The } \\
\text { University of } \\
\text { South Africa }\end{array}$ & $\begin{array}{l}\text { f Church } \\
\text { urch Polity, } \\
\text { ology, } \\
\text { retoria, }\end{array}$ \\
\hline \multicolumn{2}{|c|}{$\begin{array}{l}\text { Research Project Registration: } \\
\text { Project Leader: W.A. Dreyer } \\
\text { Project Number: } 77370920\end{array}$} \\
\hline \multicolumn{2}{|c|}{$\begin{array}{l}\text { Prof. Dr Dolf Britz is } \\
\text { participating in the research } \\
\text { project, 'Justice and Human } \\
\text { Dignity. A Reformed } \\
\text { perspective', directed by Dr } \\
\text { Wim Dreyer, Department of } \\
\text { Church History and Church } \\
\text { Polity, Faculty of Theology, } \\
\text { University of Pretoria. }\end{array}$} \\
\hline \multicolumn{2}{|c|}{$\begin{array}{l}\text { Corresponding author: } \\
\text { Dolf Britz, } \\
\text { Britz.dolf@gmail.com }\end{array}$} \\
\hline $\begin{array}{l}\text { Dates: } \\
\text { Received: } 26 \\
\text { Accepted: } 24 \\
\text { Published: } 08\end{array}$ & $\begin{array}{l}\text { pr. } 2017 \\
\text { une } 2017 \\
\text { Dec. } 2017\end{array}$ \\
\hline \multicolumn{2}{|c|}{$\begin{array}{l}\text { How to cite this article: } \\
\text { Britz, D., 2017, 'Van buite } \\
\text { bekyk: Die teologie van die } \\
\text { Nederduitsch Hervormde } \\
\text { Kerk van Afrika tussen } 1938 \\
\text { en 1950', HTS Teologiese } \\
\text { Studies/Theological Studies } \\
73(1), \text { a4605. https://doi.org/ } \\
\text { 10.4102/hts.v73i1.4605 }\end{array}$} \\
\hline \multicolumn{2}{|c|}{$\begin{array}{l}\text { Copyright: } \\
\text { (c) 2017. The Authors. } \\
\text { Licensee: AOSIS. This work } \\
\text { is licensed under the } \\
\text { Creative Commons } \\
\text { Attribution License. }\end{array}$} \\
\hline \multirow[b]{2}{*}{ 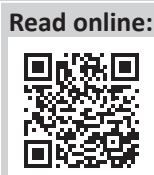 } & \\
\hline & $\begin{array}{l}\text { Scan this QR } \\
\text { code with your } \\
\text { smart phone or } \\
\text { mobile device } \\
\text { to read online. }\end{array}$ \\
\hline
\end{tabular}

This article depicts the theology of the Nederduitsch Hervormde Kerk van Afrika as embodied in especially influential ecclesiastical publications, namely Die Hervormer, the Almanak van die Nederduitsch Hervormde Kerk van Afrika and the Hervormde Teologiese Studies. These sources indicated the period between 1938 and 1950 to be of significance in the history of the formation of the theology in this church. Hence the delimitation 1938-1950. The memorial dates in 1938, 1939 and 1942 offered the church the opportunity to shape its historical existence theologically. This was done along clear-cut ecclesiastical lines. As the Voortrekkerkerk, the Hervormde Kerk was in fact a Christ confessing church of the (Afrikaner) people. By 1950 a shift in this theological image occurred: from historical identity to a contextual insistence: the racial issue. The traditional theology of the Church was accordingly adapted and contextualised in a praxis of separate development and separate churches. From its own ranks this theology was also critically questioned. The interrogation did not take its departure in either history or context, but argued the case in terms of the church of Christ.

\section{Inleiding}

Hierdie bydrae ondersoek die teologie van die Nederduitsch Hervormde Kerk tussen ongeveer 1938 en 1950, soos dit veral neerslag gevind het in Die Hervormer, die Almanak van die Nederduitsch Hervormde Kerk van Afrika en die Hervormde Teologiese Studies. In hierdie kérklike publikasies is die profiel van die teologiese en intellektuele denke eie aan en verteenwoordigend van die Hervormde Kerk die duidelikste afgeteken. Sentraal dus is die vraag na die aard en ontwikkeling van die Hervormde Kerk se teologie, soos dit in hierdie bronne en in hierdie tydperk aan die orde kom. Die tydperk 1938-1950 is gekies omdat die primêre kerkhistoriese bronne dit as 'n veelseggende periode in die geskiedenis van die vorming van die teologie van hierdie kerk aan die hand doen. Dit is derhalwe aan hierdie stel primêre bronne oorgelaat om die blik van buite te informeer.

Die gepubliseerde teologies-akademiese werk van dosente en lidmate van die Hervormde Kerk, byvoorbeeld die uitstaande kommentare van Van Selms en Gemser, is nie met dié stukkie geskiedenisteologie geïntegreer nie. Afgesien daarvan of hierdie selfstandige teologiese navorsing en bydraes noodwendig die kerklike teologie van die Hervormde Kerkverteenwoordig, sou dit die grense wat vir 'n artikel geld, geweld aandoen. Preke wat gedurende hierdie ongeveer 12 jaar gepubliseer is, is ook nie oorweeg nie. Net soos die inhoud van die teologiese opleiding, vra dit vir selfstandige studie. In 1945 het die Belydenisskrifte, Gebede en Formuliere van die Nederduitsch Hervormde Kerk van Afrika in druk verskyn. Hierin is die belydensskrifte noukeurig uit die oorspronklike tekste vir die kerk vertaal. Hoewel aansluiting gesoek is by die Afrikaanse vertaling wat in 1936 deur die Bybelvertalers op die pers gekom het, het die kommissie onder voorsitterskap van prof. B. Gemser, 'n eie en unieke vertaling besorg. Die belangrike rede hiervoor was dat die Bybelvertalers se vertaling 'gebaseer is op 'n gewysigde teks' - die Rutgers-Kuyper teks van die Drie Formuliere van Enigheid - 'wat verskillende afwykings ... vertoon, ... wat deur ons dan ook nie aanvaar is nie' (Anoniem 1945:Voorberig). Hierdie inspirerende verhaal van oorspronklike bronne-navorsing is reeds elders deur die outeur nagegaan, en word in die onderhawige artikel nie weer oorvertel nie (sien Britz 2013:6-8, 9-10).

Die fokus van hierdie artikel is dus op aard van die kérklike teologie van die Hervormde Kerk soos dit ontwikkel het tussen 1938 en 1950. Gedenkdatums het die geleentheid gebied vir historiese inkleding en teologiese singewing. 


\section{Gedenkdatums bied geleentheid vir historiese inkleding en teologiese singewing}

In die 1942 Almanak van die Nederduitsch Hervormde Kerk van Afrika skryf ds. F.J. van Zyl 'n artikeltjie oor 'Ons kerk en ons volk' (Van Zyl 1942:58-62). Hy neem sy vertrekpunt in die geskiedenis: 'Ons kerk het nog altyd by ons volk gestaan' (Van Zyl 1942:58). Dit staan dus histories vas. Dié kerk mag dus nooit vergeet 'dat hy die Boerekerk is nie, die kerk van die Voortrekkers, en derhalwe nooit mag vergeet wat sy roeping teenoor ons volk is nie' (Van Zyl 1942:58). Dié kerk staan dus in ' $n$ besondere verhouding tot die volk.

Van buite besien, is dié vertrekpunt té opsigtelik om mis te kyk. Hoe kerk en volk histories en teologies in 'n samehang ingedink is, blyk by nadere ondersoek met name uit die wyse waarop gedenkdatums tussen 1938 en 1942 betekenisvol ingeklee is. In 1938 was die teologiese opleiding van die Hervormde Kerk reeds 21 jaar gevestig aan die Universiteit van Pretoria. Gedurende dieselfde jaar is die 'Groot Trek' in 'n eeufees van nasionale omvang herdenk. 'n Jaar later is die 'koms van die Franse Hugenote' (1688) na drie eeue gevier. En, in 1942 het die Hervormde gemeente Potchefstroom sy honderd-jarige jubileum luisterryk met die kerkverband gedeel.

By hierdie gedenkdatums kon die Hervormde Kerk sy verlede bymekaarmaak en op ' $n$ nasionale niveau onthul. Die Kerk was gereed om met inbeelding en singewing historiese belang en teologiese betekenis aan die gedenkdatums, en daardeur ook aan die Hervormde Kerk, toe te reken. Met aannames is gewerk. Maar, 'n duidelik omlynde historiese identiteit is bekendgestel.

\section{Teologiese opleiding gevestig}

Klaarblyklik is die beduidende belang van die teologiese opleiding by 'Die mondigwording van ons opleiding aan die Universiteit van Pretoria 1917-1918' (sic. Lees 1938. Dreyer 1938a:1) onderskat. Immers, die tersaaklike artikels (Anoniem 1938a:9-11; 1938b:3-4; 1940:21-22; Dreyer 1938a:1; Wolmarans 1938:7-9) gee weer en lig toe, maar kom nie tot 'n beoordeling van byvoorbeeld die kurrikulum of die toepassing en impak daarvan op die kerklike lewe en samelewing nie. Die belanghebbendheid van diversiteit van die Fakulteit Godgeleerdheid aan, sedert 1930, die Universtiteit van Pretoria, word nie ingeskat nie. Dit, terwyl differensiëring die Fakulteit saamgestel en daaraan 'n eie karakter besorg het.

Prof. J.H.J.A. Greyvenstein (en sedert 1921 ook prof. S.P. Engelbrecht) het die opleiding gedeel met proff. H. Reinink (Grieks), A.C. Patterson (Hebreeus), W.A. MacFadyen (Wysgerige vakke) en E. MacMillan (Godsdienshistoriese vakke). Uit Nederland sou bykom proff. B. Gemser (1926) en A. van Selms (1935). Nadat die Universiteit in 1933 uitsluitlik vir Afrikaans as voertaal gekies het, het H.P. Wolmarans by
MacMillan in 1935 op 'n deeltydse basis oorgeneem totdat hy in 1938 voltyds professor geword het (Engelbrecht 1948:59; Mulder 1960:10; Pont II Voorwoord 2007, ongenommer, hoofstuk 4.II.4). Met sy emeritaat in 1946 sou Greyvenstein se briljante student, A.S. Geyser, hom opvolg (Anoniem 1946:12; Dreyer 1946:5).

In die gedenkjaar (1938) is die Fakulteit opgebreek in 'n Afdeling A en 'n Afdeling B, uitsluitlik vir die Nederduitsch Hervormde Kerk (Afdeling A) en vir die Nederduits Hervormde of Gereformeerde Kerk van Suid-Afrika (Afdeling B). Byna geen woord word hieroor, of die konsekwensies daarvan, vir die Universiteit én die Hervormde Kerk, gerep nie. Gedurende hierdie 21 jaar het die Fakulteit immers ' $\mathrm{n}$ taal van onderrig verloor, hy het ingeboet aan dosente uit ander kerklike agtergronde en hy is afgekamp vir teologiese opleiding aan twee onderskeie kerke.

Wat wel uit die artikels in verband met die teologiese opleiding blyk, is dat die Hervormde Kerk se opleiding ná 21 jaar blywend gevestig is. Dit het fundamenteel daartoe bygedra dat dié Kerk nou in eie reg na vore kon kom. Sy aandeel aan die geskiedenis en kerkgeskiedenis van die land kon vertolk word.

Die bakermat van teologiese opleiding by die Hervormde Kerk lê dus in die 21 jaar voordat die Fakulteit omgeskakel is in 'n kerk-eie instelling. Hierby moet die teologiese opleiding van die Nederlander, student van dr P.J. Muller, tussen 1905 en 1909, getel word. Twee leidinggewende predikante, di. J.J. Kuhn en J.J. Prinsloo, het gedurende daardie jare by hom afgestudeer (Mulder 1960:10). Muller se teologiese opleiding kan sekerlik aan die hand van sy Handboek der Dogmatiek ten dienste der Ned. Hervormde Kerk gekarteer word. 'Wat wij hier onder Dogmatiek verstaan', stel hy sy uitgangspunt, 'is het best te omschrijving, als de leer van het Christelijke geloofsleven naar de opvatting der Hervormde Kerk' (Muller 1895:1). Daarin staan reeds 'n benadering afgeteken, met 'n eties-teologiese oorweging wat ook deur die struktuur van die boek bevestig word (sien ook Engelbrecht 1953a:271-282). 'n Tweede en uitgebreide uitgawe word in 1908 in Groningen gepubliseer (Engelbrecht 1953a:276).

Die teologiese aard van die universiteitsopleiding sedert 1917 moet nog steeds in die lug bly hang. Na 21 jaar is dit nie nagegaan of daarop gereflekteer nie. Dit wag op teologieskritiese uitklaring en behandeling uit primêre bronne, waarvan die kurrikulum sekerlik die belangrikste is. Op die oog af het die opleiding diversiteit gehuisves. Vir die doeleindes van hierdie artikel is dit genoeg om, van buite gesien, die Muller- en Pretoria-opleiding tot 1938 as die aanvangsfase van teologiese opleiding by die Hervormde Kerk aan te merk. Dit beteken nie dat hierdie opleiding toe nog in sy kinderskoene gestaan het nie. My indruk is dat dit aan die gangbare standaarde van nagraadse universitêre opleiding voldoen het. Die tweede indruk is dat hierdie opleiding kerk-spesifieke en ook kerkistiese belyning oorstyg 
het. Afgesien van die aanvanklike Engelssprekende voorgangers, was nóg Gemser, nóg Van Selms van huis uit ingebed in die 'Voortrekkerker-tradisie'.

Hervormde predikante en dosente het in die jare dertig in die praktyk van die lewe te make gekry met die seggingskrag van die Afrikaner se nuutgevonde geskiedbeeld. By die ander drie genoemde gedenkdatums is die prestige daarvan vir die Hervormde Kerk skerpgepunt.

\section{Die vereenselwiging met die Voortrekkers van die Groot Trek}

Die herdenking van die 'Groot Trek' gedurende 1938 het simbolies tot uitdrukking gekom in 'n 'sinnebeeldige gedenktrek van ossewaens' uit Kaapstad oor die lengte en breedte van Suid-Afrika heen, rigting Pretoria, waar die hoeksteen van Moerdyk se Voortrekkermonument op 16 Desember in 'n volksoploop plegtig gelê is (Mostert 1940:Titelblad, 778-780). Dit het aan die Afrikaner in die besonder ' $n$ houvas op en aan die geskiedenis van die land gegee. Hy het hom bevind op die pad van Suid-Afrika, en het 'n nasionale lied ontvang om te sing: die Stem van SuidAfrika.

Die herdenking as gebeure, sowel as die geskiedenis self, is met God in verband gebring. Op 'n besondere manier was Hy die God van die Afrikaner. Immers, Hy het aan die verlede beide beslag en voortgang gegee. Met hierdie aanname is wyd en syd gewerk, sonder om dit Skriftuurlik en krities te verantwoord. God was in die openbaar op die lippe van baie meer mense as net predikante. Dit kan o.a. nagelees word in Dirk Mostert se Gedenkboek van die ossewaens 1838-1938 (1940).

Hierdie nasionale gedenkfees, wat van die Afrikaanse Taalen Kultuurvereniging op Hartenbos uitgegaan het, is gevolglik kerklik en teologies begelei. Dit is beleef as 'n ingrypende nasionale ontwaking van die Afrikanervolk en het 'n ongekende entoesiasme op tou gesit. Min het egter die bedenklike aspekte van die teologiese aannames en inkleding ondervra. By die Hervormde predikant van Johannesburg, ds. Prinsloo, het die uiterlike vertoon - voortrekkerdrag, die groei van baarde - wel nie goed aangekom nie. Daarin skuil ydelheid, ligsinnigheid (Prinsloo 1938:15). Maar, meer nog. Met verwysing na die doop van waens ${ }^{1}$ wanneer hulle amptelik hul name ontvang het, vra hy: 'Lyk dit nie al baie na Godslastering om 'n wa plegtig te doop en 'n wa plegtig toe te sing: 'Dat's Heren zegen op u daal?" (Prinsloo 1938:15). Die populêre doopsbediening aan verbondskinders by die wa-

1.In sy Gedenkboek van die Ossewaens op die pad van Suid-Afrika verhaal Dirk Mostert hierdie soort gebeure enkele kere. By die doop van die Andries Pretoriuswa, het ds. J.F. Naude (N.G. Predikant Graaff-Reinet) sy hand op die watent gelê me hierdie woorde: 'In jou sal jy die gees van Andries Pretorius dra. Ons stuur jou met sy naam op sy spoor' (Mostert 1940:255). Daarna is die Psalm waarna ds. Prinsloo sy naam op sy spoor" (Mostert 1940.255). Daarna is die Psalm waarna ds. Prinsloo verwys, spontaan gesing. Die doop van die Piet Retief-wa is deur mnr. H.J. Klopper, (voorsitter van die Uitvoerende Raad van die A.T.K.V. en Hoofleier van die Trekke) 'voltrek deur die ou vlag drie maal oor die tent te stryk ...' (Mostert 1940:324). Op Springfontein het ds. de Kock die Vrou en Moeder-wa gedoop 'deur water oor die waentjie te drup uit ' $n$ vingerhoed wat aan die moeder van Sarel Cilliers behoor het' (Mostert 1940:367). Die Johanna van der Merwe-wa is deur ds. A.D. Lückhof 'in teenwoordigheid van sowat vierduisend mense in Voortrekkerdrag ten doop gebring' (Mostert 1940:481). Ds. Prinsloo is natuurlik heeltemal reg. feestelikhede is eweneens vir hom 'n probleem. 'Word dit 'n komedie? Word die verbondsgedagte by die doop nie hier totaal uit die oog verloor nie?' Vir hom is dit 'n wesenlike gevaar dat 'ons die heilige dinge, gedryf deur ons hooglopende geesdrif, gaan ontheilig' (Prinsloo 1938:15). Klaarblyklik is hier vir die student van dr P.J. Muller, grense oorskry. Dit het egter nie die Hervormde Kerk verhoed om mee te doen nie, en ' $n$ direkte band tussen die Voortrekkers van die Groot Trek en die Kerk te lê nie.

Die Potchefstroomse redakteur van Die Hervormer, ds. Joh. Dreyer, tipeer '1838-1938' as 'n wondereeu. Daarin is gebore, skryf hy, "n nuwe taal, 'n nuwe kultuur, 'n nuwe volk en 'n nuwe kerk', bedoelende die Hervormde Kerk (Dreyer 1938c:1). Hierdie Kerk, 'n 'loot van die een, heilige, algemene, Christelike kerk' (Dreyer 1938c:3), was die kerk van die Voortrekkers. Kerkhistories lê die betekenis van die 'Groot Trek' presies hier. Die historiese Kaaps-Hollandse Kerk het hom hier op 'n eie manier en in terme van 'n eie organisasie as ' $n$ kerk onafhanklik van die Britse kolonie, voortgesit. (Dit is, terloops, die punt wat die Hervormde geskiedskrywing in die Suid-Afrikaanse kerkhistoriografie maak.)

In prof. S.P. Engelbrecht het die Hervormde Kerk 'n bekwame segsman en kerkhistorikus ontvang wat hierdie vertolking van die kerklike verlede én teologiese herkenbaarheid stewig sou vestig (Engelbrecht 1920a; 1920b; 1925; 1936; 1938; 1953b). Tewens, sy geskiedskrywing het die identiteit van die Kerk as die Voortrekkerkerk bepalend uitgemeet (sien ook Storm 1984). Hy het die grondliggende werk gedoen om hierdie paradigma in die Hervormde Kerk te populariseer én te steriotipeer. Die georganiseerde emigrasie van die jare 30 van die 19 de eeu, met sy staatkundige en kerklike gevolge, gee dus aan die Hervormde Kerk bestaansreg ... Vir ds. J.J. Prinsloo van Johannesburg kom dit neer op 'ons eersgeboortereg' (Prinsloo 1938:16).

Dié Hervormde Kerk kon hom in 1853 selfstandig organiseer in 'n Algemene Kerkvergadering, het die kerklike vereniging van die jare tagtig in 'n klein minderheid oorleef, het sy teologiese opleiding in 1917 aan die Transvaal University College in Pretoria gevestig en al sterker in eie reg na vore gekom. Hierdie geskiedenis het die Kerk gehelp om van die metodisme gevrywaar te bly en in die oriëntering aan die Nederlandse Hervormde Kerk, ook die invloed van die Doleansie en Neo-calvinisme van Kuyper te ontkom. Tipies van die Voortrekkerkerk was dus dat hy tussen die metodisme en die Neo-calvinisme deurgestuur het. Dit het hom teologies verder onderskei.

\section{Afwysend teenoor die Neo- calvinisme en metodisme}

Met die 50-jarige herdenking van die Doleansie in 1937 beskryf en beoordeel ds. J.G.M. Dreyer die 'Doleansie vrugte' (Dreyer 1937:140-152). Die goeie vrugte is die opbloei van die Calvinisme wat daaruit na vore gekom het. Maar daar is ook slegte vrugte, soos hy dit noem. Die probleem met die Doleansie en Neo-calvinisme sien hy in die verbreking van 
die relasie tussen kerk en staat, soos dit uitgedruk is in Artikel 36 van die Nederlandse Geloofsbelydenis.

Dreyer trek die konsekwensie van hierdie soort skeiding van kerk en staat deur. Op staatkundige gebied, skryf hy, beteken dit dat dit nou die owerheid vrystaan om neutraal posisie teenoor God en sy Woord in te neem. Daarmee word die soewereiniteit van die regering van Christus van die terrein van owerheid en staat uitgesluit (Dreyer 1937:142). Gesag verskuif dus, in stryd met Romeine 13, van God na die mens (Dreyer 1937:143). En die vrug hiervan, sê ds. Dreyer, is die ontkerstening van die nasie (Dreyer 1937:142). Die Christendom is nie meer openbare volksaak nie, maar word inteendeel 'n privaat aangeleentheid (Dreyer 1937:145).

Op die gebied van die onderwys word die openbare skole eweneens neutraal, om vervang te word met die (staatsondersteunde) besondere of Christelike skool en universiteit (Dreyer 1937:145). Die Hervormde Kerk sou hom laat vind vir Christelik-nasionale onderwys, maar nie vir die partikuliere Christelike skool, soos die Gereformeerde Kerke later daarop sou aandring nie (Dreyer 1949a:1, 8). Op kerklikteologiese terrein, word die kerk as instelling uit die openbare lewe gedruk om as 'n vrye kerk in afsondering te bestaan (Dreyer 1937:148). Vrye, selfstandige gemeentes kan hulle dus ook van die kerkverband losmaak, of die kerkverband geringskat (Dreyer 1937:148). Aan hierdie vrugte sou die Nederduitsch Hervormde Kerk in Afrika nie geken word nie.

Dit herhaal Dreyer in 'n artikel 'Kerk en staat' wat hy in Die Hervormer van Mei 1938 opneem (Dreyer 1938b:3-4). Hy skryf die skeiding tussen staat en kerk toe aan die Franse Rewolusie. Die kerk word buite die staatkunde gehou. Nie net was dit die oortuiging van Kuyper nie, maar in die 'Metodisme en Sektarisme' het dit eweneens 'n medestander gekry (Dreyer 1938b):

Dit is lynreg in stryd met die vaders van die hervorming wat geleer het die eenheid van Kerk en Staat en met name in stryd met Calvyn wat geleer het dat die lig van die evangelie op al die terreine van die volkslewe, ook op die terrein van die staat, moet val. (bl. 4)

Hierdie skeiding maak die kerk 'n genootskap tot nut van die algemeen (Dreyer 1941b:1).

Die Neo-calvinisme, aan die ander kant, wil volgens Engelbrecht, weer heers oor die staat. Die kerk kom dikwels teenoor die staat te staan en konflik word dus veroorsaak. Dit is eweneens in stryd met Artikel 36, omdat die kerk en die staat in onderskeiding van mekaar, wedersyds ' $n$ verpligting teenoor mekaar het (Engelbrecht 1941):

Waar dit die Kerk se taak is om die Owerheid te ondersteun en vir die Owerheid te bid, daar is dit die taak van die Staat om dit vir die Kerk gemaklik te maak om die Evangelie te verkondig en desnoods ook stoflik te help, soos nou ook dikwels nog gebeur. (bl. 103-104)

Die (Engelse) metodisme neig, volgens hom, om die kerk 'n sosiale instelling te mak omdat dit die bekering voor die wedergeboorte stel (sien ook Dreyer 1939b:4-5.) Daarom val hierdie benadering die staat heel dikwels lastig ter wille van byvoorbeeld wetgewing om sosiale euwels te bestry. Daarmee word die terrein van die staat oortree (Engelbrecht 1941:103).

Die Hervormde Kerk wil nie aan een van hierdie twee rigtings meedoen nie. By hom lê kerk en staat in 'n gebalanseerde orde. Hierdie orde is reeds volgens Dreyer, onder die Voortrekkers aanvaar. Alles in aggenome, kom dit daarop neer dat die Hervormde Kerk 'n 'volkskerk' wil wees, aldus die redakteur van Die Hervormer (Dreyer 1944:1). Dit moet so begryp word dat die Christen en ook die Christelike kerk ' $n$ roeping het ten opsigte van 'die ganse volk en nie net een of ander enersdenkende groepie nie' (Dreyer 1944). 'Dis 'n kerk', verduidelik hy aan sy lesers:

wat saamgeweef is met die volk, die ideale die karakter en die geskiedenis van die volk. ... Die volkskerk wil prinsipieel die hele volk omvat en wil die hele volk so moontlik, langs die deur God daartoe verordende middele in die kerk bring. (bl. 1)

Word die gedagte van die volkskerk verwerp, maak dit die kerk tot 'n vereniging waartoe iemand vrywillig kan toetree. 'n Volkskerk is egter ook nie 'n kerk vir die massa nie. Dit is 'n kerk waaraan 'n mens reeds behoort deur Gods beskikking kragtens geboorte en doop (Dreyer 1944:1). Nagenoeg tien jaar later sou hy weer op hierdie saak terugkom. Hy neem Hoedemaker aan die hand om sy gedagtegang te slyp. 'Die volkskerk wat ons voorstaan is nie die kerk wat die ganse volk omvat nie of die grootste gedeelte daarvan nie' (Dreyer 1953c:3) ... Dit is 'n Christokratiese kerk ... wat hom, terwyl hy Christus voor volk en owerheid bely, tot die ganse volk rig (Dreyer 1954:9). Samevattend kan gesê word dat die Voortrekkerkerk, dit wil sê die Hervormde Kerk, deur en deur 'n volkskerk is, terwyl teologiese rigtings wat dit in die wiele ry (soos die metodisme en Neo-calvinisme) hom teen die bors stuit.

Uiteraard verdien die sleutelkonsepte Voortrekkerkerk, volkskerk, metodisme en Neo-calvinisme by die Hervormde Kerk uit daardie tyd, 'n aantekening. Twee word met positiewe inhoud gevul, twee negatief afwysend. Maar, in al vier word die Hervormde kerk teologies en histories erken. Al vier funksioneer in 'n naïewe geskiedbeeld, wat nie op 'n indiepte teologies-kritiese ondervraging van primêre bronne berus nie. Daarom is daar ongenuanseerd met aannames en oorvereenvoudiging gewerk. Byvoorbeeld, die Hoedemaker-resepsie en vertolking in die Hervormde Kerk is net soos die Kuyper-resepsie en vertolking by die twee ander 'susterskerke' 'n aanpassing en ombuiging. Dit geld ook die ander konsepte, maar dit val buite die bestek van hierdie artikel om daarop in te gaan.

Daar was 'n derde gedenkdatum, wat hierdie trajek van histories-teologiese denke versterk het. Die 250-jarige herdenking van die 'koms van die Franse Hugenote' - om die populêre ontsluiting op die voet te volg - het ook in 1938 geval. Maar, dit is uitgedruk na die volgende jaar, omdat die 'Groot Trek' reeds die kalender beset het. Wat sou die Hervormde Kerk in die Franse Hugenote vind? 


\section{Die Franse Hugenote}

Die derde gedenkdatum wat dus geleentheid gebied het tot historiese assosiasie, was 'Die Hugenote Feesvierings' in 1939, 251 jaar na die aankoms van Franse vlugtelinge uit Europa. Dit is 'n uitgemaakte saak dat hulle hierheen 'gekom' het 'om die jong Afrikanervolk te verryk met die keur van die Franse volks- en sieleadel' (Dreyer 1939c:2). Dreyer (1939c) wys daarop dat die Hugenotebloed hier vermeng is met die bloed van die Geuse, wat Hollanders was, wat dieselfde beginsel van vryheid van godsdiens en gewete as die Hugenote besit het. Dan kom die assosiasie:

Op die nasate van sulke stoere vaders en vrome moeders rus 'n dure verpligting om die met bloed gekoopte vryheid van godsdiens en gewete te bewaar en ongeskonde te oorhandig aan die nageslag, om hoog te hou waarvoor Hugenoot en Geus alles veil gehad het, nl. die Woord van God en die Protestantse geloof. (bl. 4)

Ook S.P. Engelbrecht het dit oor die 'Geestelike erfgename' (Engelbrecht 1939:12-14) van die Hugenote. Dié het gehelp om in Suid-Afrika 'n nasie met 'n sterk vryheidsin (beide vir kerk en staat) te laat ontstaan (Engelbrecht 1939:14).

H.M. van der Westhuizen vind die 'christelik-etiese grondslag' van die 'calvinisties-protestantse' Hugenote (Van der Westhuizen 1939:16) vergestalt in 'n vryheidsin wat ook onder die Geuse aan die roer was. Dit is bewaar deur die Voortrekkerideale en, so trek hy die lyn deur, is dit in die 20ste eeu 'besig om op te vlam in die Boer se stryd om algehele Vryheid' (Van der Westhuizen 1939:17).

In dieselfde asem reflekteer C.K. Oberholzer oor 'Die ideologiese betekenis van die koms van die Franse Hugenote' (Oberholzer 1939:17-20). Hy bring die Afrikaner se bestaan met God in verband. 'God, as die Bron van alle wysheid, wou dat die Boerenasie hier moes word, omdat Hy 'n bepaalde plan met ons het' (Oberholzer 1939:17). Elke nasie, meen hy, is niks anders nie as die beliggaaming van 'n bepaalde Godsgedagte wat bewaak moet word teen die aanvalle van vreemde magte (Oberholzer 1939:18). Die Boerenasie kan dus nie aan toeval of noodlot toegeskryf word nie. So het die 'Afrikaanse gedagte' ontstaan. Die Afrikaanse gedagte is niks minder nie as die ideologie wat 'ons vind by die Afrikaner van die Groot Trek, by die Afrikaner van die twee republieke en ook nog die ideologie van huidige maatskaplike strewe' (Oberholzer 1939:19). Oberholzer sien 'die Afrikaanse ideologie' van eenheid, vryheid, reg en liefde, beginselvastheid, oortuigingstrou en tradisie-heiligheid, van Godsdiens en Godsvrug, van diens vir God en in God, as dit wat 'ons gedra (het) tot waar ons vandag is en hierdie ideologie is 'n erfenis van die Franse Hugenote' (Oberholzer 1939:19). Dit is hier waar die nasie en kerk staande bly (Oberholzer 1939:20).

Die assosiasie met die ingebeelde 'Voortrekkerkerk' is deur hierdie genasionaliseerde ontsluiting van die Hugenote natuurlik versterk. Trouens, in die Franse vlugtelinge gaan dit hiervolgens nie om 'n gereformeerde belydenis wat ingedra is nie, maar om vryheid en geloofsvertroue. Hierdie ontsluiting is in lyn met die Engelbrecht geskiedvertolking. Maar, daar was ook 'n vierde gedenkdatum wat vir vertolking en identifisering in aanmerking sou kom: '100 jaar kerk in die Transvaal' (Prinsloo 1942:1-2). Die gemeente Potchefstroom is in 1842 gestig, toe dus 100 jaar gelede.

\section{Die Nederduitsch Hervormde gemeente Potchefstroom herdenk sy 100 -jarige bestaan in 1942}

Ds. J.J. Prinsloo, voorsitter van die Algemene Kerkvergadering, wat sy sitting met ' $n$ jaar vervroeg het om in Potchefstroom met hierdie geleentheid saam te val, dui aan:

dat die koms en bestaan van die kerk in die Kaap en Transvaal was nie stigtings of afskeiding van 'n nuwe kerk nie, maar dit was die voortsetting en vertakking en natuurlike uitbreiding van die Ou Christelike Kerk. (Prinsloo 1942:1)

Hy praat dus van die 'ontstaan van die gemeente Potchefstroom' (Prinsloo 1942). 'Onder die gesamentlike leiding van die voormanne van die Voortrekkersvolk', skryf hy:

wat almal Hervormers was en van die leiers van die Hervormde Kerk is 'n gelofte gedoen wat deur die God van die Vaders op 16 Desember 1838 bevestig is te Bloedrivier. Die kerklike en staatkundige is in daardie jare moeilik van mekaar te skei. (bl. 1)

Die Hervormer se redakteur Dreyer 1942 bevestig aan sy lesers dat:

die trekkers ... die werktuie in die hand van God van die vaders (was) om na hierdie mooi wêrelddeel te bring die Woord van God, die Hervormde Kerk van ons vadere en die christelike beskawing. (bl. 2)

Die Voortrekkerkerk is hier gevorm en gebou met veel teenstand en teleurstelling, met moeite en teenslae, net soos die Voortrekkerstaat. Hy pak sy 'eeufeesgedagtes' in 'n historiese verhaal uit.

Na die 'Groot Trek' kon die Hervormde Kerk homself organiseer en het twee afskeurings beleef: dié van Postma en dié van Cachet (Dreyer 1942:2). Die volgende groot moment in die geskiedenis van die kerk is die kerkvereniging van die jare 80 van die negentiende eeu. Toe het die kerk deur diep waters gegaan. Omdat soveel verloor is:

Maar God het hom nie onder laat gaan nie. Daar was en is nog ' $n$ roeping vir die aloue Hervormde Kerk, wat die erfenis van ons voorvaders is en waarin al die sedes gewoontes en volkstradisies beliggaam is. (Dreyer 1942:3)

Met hulp uit Nederland kon die Kerk weer op sy voete gehelp word. Vir Dreyer (1942) is dit belangrik om daarop te wys dat in hierdie proses die predikante:

stelling ingeneem (het) teen die metodisme wat vanuit die Kaap die Transvaal ingestroom het. God het hulle gebruik om ' $n$ damwal op te werp en die stroom weer in die regte vore van ons calvinistiese volksbodem te lei. (bl. 3) 


\section{Die gedenkdatums besorg kerklike identiteit}

By die gedenkdatums is met historiese inbeelding en vertolking aan die Hervormde Kerk 'n identiteit besorg. Die teologiese aard van die Kerk is in die konsep van ' $n$ volkskerk gevind, wat die verbinding tussen kerk en staat en gemeenskap sinteties saamgevat het. Daarmee het voorgangers in die kerk hulleself doelbewus afgegrens teen beide die metodisme en die Neo-calvinisme. Hierdie posisie kon dit vir die Kerk moontlik maak om met die ideale van die Voortrekkers en hulle staat te vereenselwig. Die Hervormer het met geen voorbehoude hierdie geskiedbeeld omarm en aan die Hervormde Kerk eie gemaak.

Hierbo is verhaal hoe die gedenkdatums aan die Hervormde Kerk histories en teologies aan 'n eie identeit gehelp het. Dit is geknip op die patroon van Engelbrecht se geskiedvertolking. Hy het die basis daarvoor uitgewerk in sy Geskiedenis van die Nederduits Hervormde Kerk, soos sy 1936 weergawe daarvan geheet het (Engelbrecht 1936). Hy sluit sondermeer aan by die destyds opkomende skool van nasionalistiese geskiedskrywing en staan binne die Hervormde Kerk feitlik man alleen vir hierdie vertolking. Teologies-kritiese ondersoek en beskrywing van die kerkgeskiedenis in terme van die Kerk van Christus, het egter uitgebly. Sou dit die rede wees waarom 'n geskiedenisvertolking diens kon doen om 'n teologiese identiteit aan die Hervormde Kerk te besorg? Die Here God is daarin bygebring ... Doen dit afbreuk aan die Skriftuurlik singewing van die geskiedenis van die kerk?

\section{Geen 'Gelykstelling'}

By die gedenkdatums was dit op die agtergrond. Maar, as 'n mens die artikel moet glo, was dit'n saak na aan die kern van kerklike denke en dus algemeen geldig en aanvaar. Die Hervormde Kerk duld nog altyd geen gelykstelling nie. Die beplande veelrassige konvensie van die World Sunday School Association in Durban in 1940, het alle andersdenkendes (soos in die Hervormde Kerk ook) met veelrassigheid gekonfronteer. Hierdie saak stel die redakteur van Die Hervormer onder die opskrif 'Gelykstelling' aan die orde. Ons vaders (d.i. die Voortrekkers), teken hy aan, wou van geen gelykstelling weet nie. Daarmee is die saak uitgemaak. 'Dit was hulle strewe om hulle bloed suiwer te hou en hulle het geen bloedvermenging met naturelle en kleurlinge toegelaat nie' (Dreyer 1939a:1). Immers, beeld hy geskiedenis in, 'die land is gekoop met die bloed van die Afrikanernasie, gekoop van die naturel, oopgesit vir die beskawing en bewoonbaar gemaak vir blank Suid-Afrika' (Dreyer 1939a:1). Klink en klaar: elkeen, blank sowel as gekleurd, moet egter langs sy eie lyne ontwikkel, sy eie kultuur opbou en op sy eie geestesgoedere voortbou (Dreyer 1939a:1). Hierdie standpunt is met name deur die Londonse Sendinggenootskap ondermyn. Die soort Engelse sendelinge, beklemtoon hy op populêre hoor-sê afstand, het altyd die naturel teen die blanke opgestook (Dreyer 1939a:1).
Op die voetspoor van die Voortrekkers het die Hervormde Kerk konsekwent - 'tot vandag toe' - volgehou in sy beswaar teen gelykstelling. Hierdie beginsel word in Artikel 2, beklemtoon Dreyer, van sy destydse Kerkwet (1904) uitgespel, naamlik dat 'slegs blanke persone tot die Ned. Hervormde Kerk behoort' (Dreyer 1939a:3) en in Artikel 5 (1937) wat lui: 'die Kerk gaan uit van die beginsel van onderskeid tussen blankes en nie-blankes en erken geen gelykstelling tussen blank en nie-blank nie' (Dreyer 1939a:3). In Durban sal die Hervormde Kerk dus nie deelneem nie. Hy handhaaf die 'kleurskeidslyn'. Die 'Voortrekkerkerk' en 'geen gelykstelling' het mekaar geïmpliseer en mekaar aangevul. Nog 'n konsep is gemunt om die teologiese-historiese identiteit van die Hervormde Kerk af te tree.

By die 'mondigwording' van die teologiese opleiding aan die Universiteit van Pretoria is die teologiegeskiedenis van die Hervormde Kerk nie in behandeling geneem nie. Daar was geen bestekopname nie. Dit wag nog op ondersoek. Die teologie van dié Kerk is wel vasgelê in 'n geskiedbeeld, wat by historiese gedenkdatums in terme van die gangbare geskiedskrywing, ontknoop is. Hierbo is enkele tipiese denkbeelde uit die primêre bronne opgediep en bespreek. Hulle word die draers van 'n teologie. Gedenkdatums het hulle help skep.

Die Kerk kon nie net identifiseer met 'n geskepte geskiedbeeld nie, maar is juis daarom ook gedwing om posisie in te neem ten opsigte van met name hulle wat buite die blanke kring staan, maar dieselfde geskiedenis en land gedeel het. Die Kerk het 'n skans hierteen opgewerp: 'geen GelyksteIling'. Dié skans sou in die toekoms al meer in die spervuur kom. Hiermee sou die teologie van die Hervormde Kerk al meer te make gekry het, dit wil sê:

op die plek en in die kring waarin ons ons deur God geroepe en gestel ag in die kerk waarin na ons oortuiging die stroom van die Bybelse waarheid, soos in die Hervorming opnuut tevoorskyn getree, kragtig en suiwer voortstroom: die Hervormde Kerk. (Redaksie 1943:1)

Hierin gaan dit om die Bybel, 'die lewende water van die direkte onafgeleide Godsopenbaring', skryf die Redaksie van die nuwe tydskrif Hervormde Teologiese Studies in 1943, 'op die fondament wat met die kerkhervorming' (Dreyer 1943:3) gelê is. 'Die suiwer reformatoriese beginsels wil ons handhaaf, verdedig en aksentueer. En wat on-reformatories is wil ons weer' (Dreyer 1943:3). Immers, die tydskrif is in die lewe gebring 'vir die bevordering van die Bybels-Reformatoriese teologie in Suid-Afrika' (Hervormde Teologiese Studies [1], 1943-1944).

Die onmiddellike vraag (ook van die buitestander) is of die (voorgenome) Bybels-reformatoriese teologie die historiesteologiese identifisering by die gedenkdatums bepaal het. Dit lyk of ds. van Zyl in 1942 van die teendeel oortuig was. 'Ons kerk', skryf hy, 'het nog altyd by ons volk gestaan' (Van Zyl 1942:58). 


\section{Ons Kerk het nog altyd by ons volk gestaan}

Wie die artikel van Van Zyl lees, word egter met die onverwagse oorval. By hom lê die kerk in ander voue as dié van die volk. Hy begin by die kruis! Die kerk, skryf hy, staan op die kruis. Dit is sy wese. Hy neem nie standpunte in oor die oorlog en oor volksake nie. Die kerk is van God gegee. Die kerk is dus daar waar die gekruisigde Christus verkondig word. Alleen daar (Van Zyl 1942:59). 'Die gelowiges is die kerk, die geloof in die werk van Christus is die enigste voorwaarde vir lidmaatskap van die kerk van Christus' (Van Zyl 1942:59). Dit is waarom die kerk ook rondom die kruis is. Derdens is die kerk onder die kruis. Dit dui die opdrag van die kerk aan. Die geopenbaarde werk van Christus is die oorsprong van die kerk, en die verkondiging van hierdie werk is die opdrag van die kerk (Van Zyl 1942:59). Die kerk onder die kruis dui ook die gebondheid, die vryheid en die stryd van die kerk aan. Die kerk is gebonde: alleen die kruis word verkondig; die kerk is vry om nie onder nie, maar in die koninkryke van die wêreld die evangelie te verkondig; die kerk stry te midde van vyande van die kruis. In soverre die kerk dus getrou is aan sy opdrag, in die mate is hy kerk van Christus, trek ds. van Zyl sy gevolgtrekking (Van Zyl 1942:59).

As die kerk self magtig lyk, het hy sy sin verloor. 'Daar sal wantroue teen so 'n kerk ontstaan' (Van Zyl 1942:60). As die kerk na die mond van een of ander party praat, verloor hy sy vryheid en word verneder tot propagandamiddel vir die party: 'So 'n kerk sal deur God verlate wees, en elkeen wat die Kerk daartoe bring, 'n verraaier van die wese van die kerk' (Van Zyl 1942:60).

Wat die Hervormde Kerk betref, is nog altyd - dit is 'n historiese uitspraak - probeer om die ander terreine te vermy en alleen die klem te laat val op die prediking van die Evangelie (Van Zyl 1942). In 'ons kerk' gaan dit alleen om God en sy Woord. Die hedendaage aandrang:

om in ons land alleen een groot Afrikaanse kerk te hê, wat die volk dan ook een groot geheel sal maak en wat alle gevare wat die kerk bedreig gesamentlik die hoof sal bied (bl. 60)

getuig van optrede in eie krag. Dit kan nie. Die krag van die kerk lê in die prediking van Christus.

Hierbenewens: 'Ons kerk beperk hom tot sy klein hoekie uit respek vir die opdrag en bevel van God waarmee die kerk staan of val' en ook met verwagting dat in die suiwere bediening van die Woord en regte bediening van die sakramente meer gedoen word en beter gedoen word as met die beste bedoelings op ander terreine van die lewe (Van Zyl 1942:61).

In die lig van dit alles kom hy ten slotte tot die vraag: Wat is die taak van die kerk teenoor ons volk? Op grond van Genesis 11 en 12 onderskei hy die volkere van die wêreld (i.t.v. bloed, ras en bodem) van die volk van God, 'wat in die nuwe verbond niks anders aandui as die kerk van Christus nie' (Van Zyl 1942:62). Die taak van die kerk ten opsigte van die volk kan dus 'alleen maar wees, in die uitvoering van sy Godgegewe opdrag, dat die volk in die Kerk die vrye en suiwere Woord van God kan vind ... alleen deur die prediking van die Evangelie volgens die Skrif' (Van Zyl 1942:62). Die kerk het dus 'n sendingtaak sodat, deur die gepredikte Woord, 'ook ons volk wat ' $\mathrm{n}$ volk van die wêreld is, gevoeg mag word tot die kring van die gelowiges, die volk van God, die enigste volk wat 'n toekoms het' (Van Zyl 1942):

Wanneer die eerste en hoogste verlange van elke lid van die volk is dat die hele volk volk van God mag wees, dan eers word die ware Christelike geheiligde nasionalisme gebore. (bl. 62)

Verseker hoor 'n mens, benewens die reformatore, op 'n instemmende noot, ook Karl Barth by hom (Van Zyl 1942:60). Oor Barth se Skrifbeskouing sou hy in die eerste uitgawe van Hervormde Teologiese Studies 'n bydrae lewer (Van Zyl 1943:124-135) en nog later 'n reeks artikels oor die doop by Barth (Van Zyl 1948; 1949a; 1949b; 1949c; 1949d; 1949e). Teen 1942 was Barth al bekend in Suid-Afrika. Tewens, die Hervormde predikant ds. J.J. Strijdom sou die eerste uit die geledere van die Afrikaanse kerke van gereformeerde belydenis wees om met Een studie over den samenhang en de betrekking van Barth tot Calvijn in den 'Philipperbrief' (Strijdom 1931) aan die Universiteit van Leiden te promoveer. Daarin is hy bygestaan deur proff. de Zwaan en Haitjema (Strijdom 1931:vii). Trouens, die resepsie van Barth by die Hervormde Kerk was beïnvloed deur dié van die Nederlands Hervormde Kerk en is derhalwe veel meer aanklank by hom gevind as byvoorbeeld waartoe die Gereformeerde Kerke in Suid-Afrika (en die NG Kerk) bereid was. Laasgenoemde kerke het met Barth kennis gemaak deur middel van die Gereformeerde Kerke in Nederland, wat hom krities afgewys het (sien bv. Coetzee 1931; Du Preez 1954; De Wet 1931; Heyns 1954; Kempff 1949; Potgieter 1954; Snyman 1940; Van der Walt 1941).

Vergelyk 'n mens nou die lyn van denke van ds. Van Zyl met die histories-teologiese trajek wat by die gedenkdatums met soveel oortuiging gestel is, is die verskille ooglopend. Anders as die gedenkdatumlyn kan die kerk by Van Zyl nie 'n medewerker aan volksake wees nie. Dit voer die kerk weg van sy eintlike sin en betekenis (Van Zyl 1942:61). Hier is die geloof in die werk en geskiedenis van Christus die enigste voorwaarde om lid van die kerk van Christus te wees. Die geskiedenis van die volk tel hierin nie mee nie.

Hierteenoor, het Dreyer nog die vorige jaar daarvoor ruimte gemaak dat die kerk 'moet meestry in die vraagstukke van die volk' (Dreyer 1941a:2). En, in 1944 sou hy beklemtoon dat die ware volkskerk (soos die Hervormde Kerk) 'saamgeweef is met die volk, die ideale, die karakter en die geskiedenis van die volk' (Dreyer 1944:1). Hy het nie in leer gegaan by Obbink, van wie hy reeds in 1939 'n artikel met dieselfde strekking as dié van Van Zyl vir lesers van Die Hervormer opgesom het nie (Dreyer 1940:1-2).

Van buite beskou, ondervra Van Zyl die populêre teologiese aannames skerp en krities, maar sonder om die konsekwensies 
direk uit te spel. Hy verteenwoordig ten minste 'n kritiese stem, Bybels-reformatories gemotiveer. Hy het 'n vlaggie opgesteek.

\section{Die krisis in die kerk}

Die jong professor aan die Fakulteit Teologie (Afdeling A), dr A.S. Geyser, sou dit ook doen. Na die Wêreldoorlog skryf hy 'n lang reeks oor 'Die krisis in die kerk' vir Die Hervormer. Met die intrapslag merk hy op dat as die kerk ophou om Christus te bely kom daar 'n ander inhoud, 'n magspolitieke, in die plek daarvan en word die kerk 'n instituut van maatskaplike welsynspleging. 'Hoe nuttig die kerk dan ook in volksbelang, die politieke belang, mag wees, dit vaar onder valse vlag' (Geyser 1948a:5).

Hy bedoel dit nie net in die algemeen nie, maar sny ook aan eie kerklike vlees. Hy het die 'Boere-kerk' in die oog. Hierdie kerk word in sy materiële voorspoed arm terwyl hy onder die toename van sy invloed in wêreldlike kringe besig is om sy gesag in geestelike aangeleenthede te verloor (Geyser 1948a:6). Dat die kerk dit besef, sien 'n mens volgens hom in sy verbeterde organisasie, sy intensiewer maatskaplike welsynspleging, sy ingrypende politieke en ekonomiese deelname, kommissies, rade en afvaardigings na ministers en volksraadsittings om 'sy verglydende houvas oor ons christelike volk te behou' (Geyser 1948a:6-7).

Die krisis is dat die kerk, met sy deelname aan hierdie dinge, nie daarin slaag om sy gesag in geestelike dinge te verhoog nie. Inteendeel, hy verhoog net wantroue in hom:

omdat hy opsigtelik te kenne gee dat hyself nie glo in sy eintlike boodskap nie en hy daarom sy gesag 'n onderbou van materiële mag en wêreldlike aansien moet gee. (Geyser 1948a:7)

Geyser is konsekwent. Hy pas sy teologiese oortuiging vreesloos toe. "n Boere-kerk met sy party-politieke deelname, sy ekonomiese invloede, sy maatskaplike voortreflikheid, mag 'n nasionale kerk wees, maar het opgehou om Christuskerk te wees' (Geyser 1948a:7). Dit alles gebeur, skryf hy peilreguit, 'as jy die woorde van jou Heer vergeet: My koninkryk is nie van hierdie wêreld nie' (Geyser 1948a:7).

Dié kerk kan wel aangespreek word, maar dan vanuit skuldbelydenis en Christusbelydenis. In hierdie volgorde, want sy toestand het met homself te doene, en nie met die krisis van die wêreld nie (Geyser 1948a:5).

Die volgende aflewering (Geyser 1948b) is gebou op bogenoemde fondament. Daarin onderstreep hy dat die kerk moet waak teen die eiegeregtigheid, onopregtheid, selfsug en selfregverdiging van die volkere en die mense, veral in 'n christelike wêreld. In sy 'offensief' in die wêreld gaan dit om die 'bestendiging van Gods geregtigheid en naaste-liefde' (Geyser 1948b:5). Gedurende die oorlog het die kerk nie die standpunt van Christus ingeneem nie maar hom eerder laat vind vir die standpunte van die verskillende volke. Dit is die krisis van die kerk. Maar, skryf hy, dit geld ook vir 'ons land en ons kerk' (Geyser 1948b:5). Die kerk is nie neutraal nie - hy is God se boodskap vir geregtigheid - maar die kerk is beslis nie nasionaal nie. Hy kan en mag dit nooit wees nie. Hy behoort nie aan die nasies nie maar aan Christus (Geyser 1948b:6). Het Barth in hierdie segswyse medeseggenskap?

Weer pas Geyser dit toe op die Hervormde Kerk: 'En as die uitdrukking "christelik-nasionaal" in Artikel 9 van ons Kerkwet moes inhou 'n nasionale toe-eiening en afbakening van die Kerk, dan sou dit misleidend en gevaarlik wees', skryf hy, 'en dan moes dit liewer geskrap word' (Geyser 1948b:6). Die Kerk is nie 'n instelling ten behoewe van die volk nie, maar ten behoewe van die volk van God wat hy geroep het uit alle volkere. In hierdie sin is die kerk 'bowenasionaal' (Geyser 1948b:6).

'n Nasionale kerk staan in diens van sy volk om sy volk se ongeregtigheid en eiegeregtigheid goed te praat. Hy word sodoende die 'agterryer' van die nasies (Geyser 1948b:6). Dit beteken nie dat Christus nie meer by die kerk staan nie. Hy is wel daar, maar nou staan die skuldbelydenis in diens van die Christusbelydenis (Geyser 1948b:6).

Nadat Geyser híérdie teologiese fondasie gegooi het, pas hy dit in die vervolgartikels toe in en aan die praktyk van die Hervormde kerklike lewe. Sy uitgangspunt maak dit onmoontlik om aan 'n toepassing gestalte te gee soos diegene wat uit 'n historiese identiteit aan die roeping van die volkskerk prakties omlyning wou gee. Daarom skryf hy in nog vyf aflewerings oor die duur gekoopte vryheid van die kerk, die organisasie van die kerk, die diens van die ampte en die gevaar van magsametrekking in enkele ampsdraers, oor die predikante, oor die voorsiening van predikante, en die gemeenskap van die heiliges (sien Geyser 1948c:6-8; 1948d:8-10; 1949a:11-12; 1949b:7-8). Dit gaan vir hom nie oor die Christusbelydende volkskerk nie, maar om die kerk van Christus.

Die vlaggie wat Geyser opsteek, het eweneens 'n onverbloemde christologiese voorrang. Saam met Van Zyl is die mees fundamentele vrae dus aan die histories-teologiese identifisering van die Hervormde Kerk gevra. Op 'n rustige manier kon hulle kritiek nie deurdink of opgeneem word nie. Teen die tyd dat Geyser in volle eerlikheid die Kerk geweeg het, het die histories-teologiese lyn nuwe momentum gekry. Dit sou nie bly steek by grasie van gedenkgeleenthede nie. Het dit saamgehang met die opgang van die Nasionale Party ná die Oorlog? Die invloed van die Ossewabrandwag? Die Broederbond? Dit moet in navorsing nog uitgeklaar word. Feit bly staan, die konteks het in die kerk se tien jaar oue histories-teologiese identiteit nuwe lewe ingeblaas.

\section{Die skuif van die geskiedenis na die konteks}

Toe die 1948 verkiesingsuitslag bekend geword het, so berig Die Nuwe Perdeby, studenteblad van die Universiteit van Pretoria op 04 Junie 1948, het 'ongekende tonele van geesdrif soos nog nooit in Tukkieland ervaar is nie' (Anoniem 1948:1) hulle afgespeel. Voor die Letteregebou (waar Teologie gesetel 
was) het honderde studente bymekaargekom. Rektor Rautenbach het die studente toegespreek. 'Ons moet grootmoedig en groot wees in alles waarin 'n klein volk groot kan wees', (Anoniem 1948:3) het hy gesê. 'Onder plegtige stilte is die Vierkleur gehys, en nadat die volkslied gesing is, het die gejuig opnuut losgebars' (Anoniem 1948:3). Onder die dosente, wat elkeen 'n paar woorde tot die studente gerig het, was prof. H.P. Wolmarans en sy Afdeling B en N.G. kollega, prof. J.H. Kritzinger (Anoniem 1948:3). In die lysie ontbreek die name van proff. Geyser, Van Selms, Gemser, Engelbrecht ... Iets het in die land gebeur. 'n Nuwe fase in die geskiedenis is betree. Daarvoor sou Apartheid sorg.

Dít het aan die histories-teologiese inbeelding by die Hervormde Kerk nuwe momentum gegee. Die nuwe momentum was dus kontekstueel van aard. Hier lê die wissel. Die onmiddellike situasie sou die histories-teologiese singewing benut en verder voer om die Kerk se teologie onmiddellike en praktiese betekenis te gee. Wat hierin van deurslaggewende belang was, was wat die nuwe Eerste Minister, dr D.F. Malan, ná sy oorwinning só onder woorde gebring het:

Ons erken dan ook die groot betekenis van die Christelike godsdiens en die onmisbaarheid van die kerk met sy suiwerende en opbouende invloed op ons volkslewe. Met die kerk in al sy vertakkinge wil ons daarom op gemeenskaplike gebied ook samewerking soek. Op hierdie belangrike tydstip veral, maar ook voortdurend hierna, vra ons dan ook met vrymoedigheid die kerk se belangstelling en voorbidding. (Dreyer 1948:2)

Die voorbidding is onderneem deur die Hervormde Kerk, kragtens Artikel 36 van die N.G.B. en 1 Timoteus 2:1-3 (Dreyer 1948:2).

Hervormde samewerking sou gegee word. Immers, vir die volks- en Voortrekkerkerk het 'n geleentheid hom voorgedoen wat ter wille van die evangelie benut moes word. Vir die uitgangspunte van die histories-teologiese trajek het hierdie toedrag van sake soos 'n handskoen gepas. Dié geleentheid om mee te doen aan 'n nasionale saak - die rassevraagstuk moes aangegryp word. Immers, by die volkskerk lê die evangelie in ander voeë as by die uitsluitlike Christuskerk waaroor Van Zyl en Geyser dit het. By die volkskerk lê die staat ook anders. Daarin word die staat nie net as 'n medeinstelling van God erken nie. Ook word politieke, ekonomiese en sosiale aangeleenthede nie onbetwis aan die staat oorgelaat nie. Dit is ook te eensydig vir hierdie benadering om die kerk, soos Geyser, teenoor die staat te stel en in die lig van Gods Woord te veroordeel wanneer 'n 'owerheid die weg van die gelowige tot God versper' (Geyser 1948a:6). Het die aandrang van die konteks veroorsaak dat die Hervormde Kerk katvoet genoeg sou wees om hierdie troebelwaters (om die Van Zyl-Geyser lyn van denke oor die wese van die kerk by te haal) eers goed deur te kyk?

Die vroeëre histories-teologiese trajek met sy bybehorende konsepte, waaroor hierbo veel geskryf is, het hom nou laat geld by 'n kontekstuele probleem: die beleid van aparte ontwikkeling. Die Christusbelydende volkskerk sou hierdeur gekonfronteer word. Vir die volgende 15 jaar tot ongeveer 1963, het hierdie sterk meesleurende stroom die Hervormde Kerk laat deel in die behoud én verdediging van die beleid van afsonderlike ontwikkeling. Wat in die enkele artikel oor 'Gelykstelling' in 1939 breedweg opgemerk is, het nou 'n sentrale tema in Die Hervormer geword. En, dit is gekoppel aan 'n roeping, wat opgevolg moes word.

Einde 1949 en begin 1950 het ds. A.G.J. Oosthuizen vir Die Hervormer se leeskring die kerklike weg met betrekking tot 'Die Christelike Kerk en die naturel' uitgestippel. 'Die feit bly', open hy sy argument, 'dat ons verhouding tot die naturelle en kleurlinge ' $n$ saak is wat die Christelike Kerk ten seerste raak, en dat ook ons Kerk hierin sy stem moet laat hoor' (Oosthuizen 1949:8). Ongevraagde inmenging uit watter hoek ook al, is onwelkom. Hy voorsien dus dat al hoe meer druk op blankes sou kom om alle politieke en sosiale voorregte met die naturel te deel (Oosthuizen 1950a:3). Dit sal afronding van die einde beteken. 'Ons kan die monument maar platskiet met dinamiet. Dan het ons die oorwinning wat God ons by Bloedrivier gegee het, omgeskep in die grootste nederlaag denkbaar' (Oosthuizen 1950a:3). SuidAfrika sal dan gestalte kry in geheel en al 'n ander soort staat (Oosthuizen 1950a:3). In hierdie doodloopstraat sal die Hervormde Kerk nie beland nie. Heeltemal aparte state blyk, wat hom betref, die enigste Christelike oplossing te wees (Oosthuizen 1950b:1). Dit is die uitdaging.

Tien jaar later sou hy steeds voet by stuk hou. Lank voor 'ons rasseprobleem' (sien Dreyer 1952a; 1952b; 1953a; 1953b) 'n politieke vraagstuk was, het die kerk standpunt ingeneem 'dat hy op kerklike akker geen deurmekaarboerdery wil hê nie' (Oosthuizen 1960:18). Die Hervormde Kerk het instinktief aangevoel dat ' $n$ 'deurmekaarboerdery' tot die bitterste wrywing, geknoei en uitoorlêery sou lei. Die Kerk is dus, so stel hierdie voorman dit in 'n segswyse wat sekerlik by 'n groot deel van die volk sou afgaan, 'vandag meer as ooit oortuig dat deurmekaarboerdery of veelrassige kerk en staat nie aanvaarbaar is nie' (Oosthuizen 1960:18). Ook professor Wolmarans praat in hierdie rigting. Hy (1953:100-112) vind 'die grondslag vir die godgewe roeping' van die Kerk in die christelik-nasionale lewens- en wêreldbeskouing wat die fondament vorm 'waarop die rassebeleid van die Afrikaner gebou moes word en die sleutel moes gee ... vir die rasseprobleem' (Wolmarans 1953:102; sien ook Van den Berg 1954:86-95).

Samevattend: Sonder om, soos die twee ander Afrikaanse kerke van gereformeerde belydenis, hierdie saak Skriftuurlik te regverdig, sou die Hervormde Kerk se segsmanne dit langs prakties-realistiese lyne beredeneer as die beste oplossing. 'Eers as elke volksgroep', merk Dreyer in 1947 al op, 'langs sy eie weg tot mondigheid gelei is, sal die tyd leer hoe daar 'n gelykwaardige samewerking kan kom en nie so 'n heterogene en onwaardige afskeepery soos ons vandag aanskou nie' (Dreyer 1947:10).

Hierdie aanhalings illustreer hoe die kontekstuele trajek van denke gedurende die vyftiger-jare sy verloop geneem het. By 
gedenkdatums 1952 en 1953 (sien Anoniem 1952:3; Dreyer 1949b:3; Viljoen 1953:6) het die filantroop-sendelinge Read, Kemp en Philip deurgeloop. Hulle was immers te vinde vir 'n veelrassigheid waarmee die Hervormde Kerk nie kon saamgaan nie. Dat hulle daarvoor geagiteer het, het verdere aanstoot gegee (Dreyer 1950:3). En dan is die roeping om die blanke beskawing en die Chrislike voogdyskap teenoor die nie-blanke volke te behou, hier eweneens ingebou. Die kerkvolk sou getrou hieraan gevolg gee.

Dit is dus baie duidelik dat daar rondom 1950'n ontwikkeling in die Hervormde teologie gekom het, wat gedurende die volgende dekade in 'n duidelike kerklike standpunt uitgewerk is. Net soos in die jare veertig, was daar ook grondige ondervraging, aangedring op verantwoording en het die kritiese stem daarteen steeds aansluiting gevind by die uitgangspunte van Van Zyl en Geyser (sien bv. Geyser 1960; Redelinghuys 1960; Stutterheim 1955; 1960; Van Selms 1935:ongedateerd; Van Zyl 1955). Weer was dit Van Zyl wat gevra het: 'Het die politiek en veral ons nasionalisme nie tot 'n groot mate die plek van die eintlike voorwerp van ons toewyding ingeneem nie? ... Is die kerk nog kerk soos God hom bedoel het?' (Van Zyl 1955:15). In 1949 het Geyser reeds opgemerk dat die kerk tog bo die grense van ras en nasionalisteit uitstyg (Geyser 1949b:7). Hierdie lyn het dus ook voortgang gevind. Maar ook hier het 'n skuif gekom: van die Christologie na die ekklesiologie, met name na die eenheid van die kerk.

Hierdie pakkende verhaal kan net in 'n opvolgstudie tot sy reg kom. Die tyd het aangebreek om nou tot 'n oorhoofse gevolgtrekking te kom.

\section{Konklusie}

Oorhoofs, so lyk dit vir die buitestander, is die teologie van die Hervormde Kerk diepgaande beïnloed deur die voorsegging van die Afrikaner se geskiedenisbeeld uit die twintigste eeu. Die gedenkdatums rondom 1938-1942 het 'n historiese bewussyn in die kerklike gemeenskap losgemaak wat ekklesiologiese en teologiese identifisering aan die hand gedoen het. In die geskiedenis van die land het die Hervormde Kerk sy plek gevind en sy teologie vir die kerklike gemeenskap oor hierdie boeg uitgespel. Die Voortrekkerkerk sou histories en teologies ' $n$ volkskerk wees. Van hieruit is die bediening ingerig en bekendgestel. By gedenkdatums is rondom 1938 aan die historiese bestaansreg van die Kerk teologiese beslag gegee.

Dit is uit die bronne ook duidelik dat daar rondom 1950 'n verskuiwing plaasgevind het. Van die historiese identiteit na 'n kontekstuele aandrang: die rassevraagstuk. Dít het op 'n praktiese 'nugtere' toepassing van die teologie van die Hervormde Kerk as volkskerk aangedring.

Tog is die teologie van die Hervormde Kerk oor die tydperk wat vir hierdie artikel uitgesit is (1938-1950) daarmee nie in kruike en kanne gebring nie. Daar was 'n duidelike protesstem. 'n Stem wat in die jare veertig die kerk van
Christus opgeweeg het teen die volkskerk van die geskiedenis, en in die jare vyftig die eenheid van hierdie kerk sou beklemtoon teenoor afgegrensde volke en volkskerke. So is die Hervormde Kerk ook teologies-krities begelei. Al moes laasgenoemde die spit afbyt.

Nadat al die bronne deurgekyk en uitgesif is, is dit Geyser se opmerkings wat telkens terugkeer. In September 1948 skryf hy: ' $n$ Nasionale kerk staan in diens van sy volk om sy volk se ongeregtigheid en eiegeregtigheid goed te praat. Hy word sodoende die 'agterryer' van die nasies (Geyser 1948b:6). Dit beteken nie dat Christus nie meer by die kerk staan nie. Hy is wel daar, maar nou staan die skuldbelydenis in diens van die Christusbelydenis (Geyser 1948b:6).

Daarmee word die buitestander opeens 'n medestander. 'n Aangesprokene.

\section{Erkenning Mededingende belange}

Die outeur verklaar dat hy geen finansiële of persoonlike verhouding(s) het wat hom op 'n voordelige of nadelige wyse by die skryf van die artikel beïnvloed het nie.

\section{Literatuurverwysings}

Anoniem, 1938a, 'Die geskiedenis van die Teologiese Fakulteit', Die Hervormer XXVIII(39), 9-11.

Anoniem, 1938b, 'Die feesviering in verband met ons teologiese opleiding', Die Hervormer XXVIII(40), 3-4.

Anoniem, 1940, 'Toespraak gehou deur Mevr. Prof. Dr. Greyvenstein tydens die kongres', Die Hervormer XXXI(65), 21-22.

Anoniem, 1945, Belydenisskrifte, Gebede en Formuliere van die Nederduitsh Hervormde Kerk van Afrika, sonder uitgewer, Pretoria.

Anoniem, 1946, 'Prof. Dr Greyvenstein aanvaar sy emeritaat', Die Hervormer XXXVIII(9), 1-2.

Anoniem, 1948, 'Verkiesingsuitslae verrassend. Tukkies geesdriftig', Die Perdeby VIII(13), 1, 3 .

Anoniem, 1952, 'Jan van Riebeeck gehuldig', Die Hervormer XLIV(1), 3.

Britz, R.M., 2013, 'Die eerste vertalings van die Heidelbergse Kategismus in Afrikaans', In die Skriflig/In Luce Verbi 47(2), 1-12. https://doi.org/10.4102/ids.v47i2.668

Coetzee, J.V., 1931, 'Die leer van die predistinasie, sonde en verlossing by Barth en Kalvyn', Die Wagtoring 3(17), 1-19.

De Wet, C.J.H., 1931, 'Karl Barth (Die jongste teologiese rigting)', Die Wagtoring, 3(15), 1-19.

Dreyer, J., 1938a, 'Die mondigwording van ons opleiding aan die Universiteit van Pretoria 1917-1918', Die Hervormer XXVIII(39), 1.

Dreyer, J., 1938b, 'Kerk en Staat', Die Hervormer XXVIII(39), 3-4.

Dreyer, J., 1938c, '1838-1938', Die Hervormer XXVIII(45), 1, 3, 4.

Dreyer, J., 1939a, 'Gelykstelling', Die Hervormer XXVIII(48), 1, 3.

Dreyer, J., 1939b, 'Teenstand teen metodistiese praktyke bestempel as Satans werk', Die Hervormer XXVIII (48), 4-5.

Dreyer, J., 1939c, 'Hugenote Feesvierings', Die Hervormer XVIII(55), 3-4.

Dreyer, J., 1940, 'Die Christen en oorlog', Die Hervormer XXXI(64), 1-2.

Dreyer, J., 1941a, 'Die kerk, die politiek en die party-politiek', Die Hervormer XXXII(74), $1-2$.

Dreyer, J., 1941b, 'Die kerk, die politiek en die party-politiek', Die Hervormer XXXII(75), $1-3$.

Dreyer, J., 1942, 'Eeufeesgedagtes', Die Hervormer XXXIII(85), 2-4.

Dreyer, J., 1944, 'Volkskerk', Die Hervormer XXXVI(1), 1.

Dreyer, J., 1946, 'Prof. Dr A.S. Geyser', Die Hervormer XXXVIII(2), 5.

Dreyer, J., 1947, 'Geen Herrenvolk-Mentaliteit', Die Hervormer XXXIX(7), 9-10.

Dreyer, J., 1948, 'Voorbidding gevra deur die owerheid', Die Hervormer XL(4), 2.

Dreyer, J., 1949a, 'Christelik Nasionale Onderwys', Die Hervormer XLI(7), 1, 8.

Dreyer, J., 1949b, 'Voortrekkermonument simbool van vryheidsdrang en geloofsvertroue', Die Hervormer LXI(9), 3. 
Dreyer, J., 1950, 'Die tweede “Zwarte Ommegang"', Die Hervormer XLI(12), 3.

Dreyer, J., 1952a, 'Ons rasseprobleem', Die Hervormer XLIV(9), 1, 11.

Dreyer, J., 1952b, 'Ons rasseprobleem', Die Hervormer XLIV(9), 1.

Dreyer, J., 1953a, 'Ons rasseprobleem', Die Hervormer XLIV(10), 1, 11.

Dreyer, J., 1953b, 'Ons rasseprobleem', Die Hervormer XLIV(11), 8.

Dreyer, J, 1953c, “n Volkskerk! ... Waarom nie?', Die Hervormer XLV(2), 3.

Dreyer, J., 1954, 'Tweërlei beskouing oor 'n volkskerk', Die Hervormer XLVI (7), 9, 16.

Dreyer, J.G.M., 1937, 'Doleansie vrugte', in Dreyer, Joh. (Red.), Almanak van die Nederduits Hervormde Kerk van Afrika 1937, Jaargang 31, pp. 140-152, Algemene Vergadering van die Nederduits Hervormde Kerk, Pretoria.

Dreyer, T.F.J., 1943, 'Welkomswoord', Hervormde Teologiese Studies 1, 2-3. https:// doi.org/10.4102/hts.v1i1.3303

Du Preez, A.B., 1954, 'Die kinderdoop in die lig van die moderne teologie', Die Gereformeerde Vaandel XXIII(3), 3-21.

Engelbrecht, B.J., 1953a, 'Professor Dr P.J. Muller as dogmatikus', Hervormde Teologiese Studies 9 (3/4), 271-282. https://doi.org/10.4102/hts.v9i3/4.3682

Engelbrecht, S.P., 1920a, Geschiedenis van de Nederduitsch Hervormde Kerk in Zuid-Afrika sedert de Groote Trek tot aan de eerste annexatie van Transvaal, J.H. de Busy, Amsterdam.

Engelbrecht, S.P., 1920b, Geschiedenis van de Nederduits Hervormde Kerk in ZuidAfrika Deel I, J.H. De Busy, Amsterdam.

Engelbrecht, S.P., 1925, Geschiedenis van de Nederduits Hervormde Kerk in Zuid-Afrika Deel II, J.H. De Busy, Pretoria.

Engelbrecht, S.P., 1936, Geskiedenis van de Nederduits Hervormde Kerk van Afrika, J.H. de Busy, Pretoria.

Engelbrecht, S.P., 1938, 'Kerklike toestande onder die Voortrekkers ten weste van die Drakensberge, tot op die jaar 1842', Die Hervormer XXVIII(46), 11-14.

Engelbrecht, S.P., 1939, 'Geestelike erfgename', Die Hervormer XVIII(55), 12-14.

Engelbrecht, S.P., 1941, 'Die Ned. Hervormde Kerk en die politiek', in Engelbrecht, S.P. (Red.), Almanak van die Nederduitsch Hervormde Kerk van Afrika 1941, Jaargang 35, 103-109, Algemene Vergadering van die Nederduitsch Hervormde Kerk, Pretoria.

Engelbrecht, S.P., 1948, Historiese-Album van die Nederduitsch Hervormde Kerk van Afrika, J.H. de Busy, Pretoria.

Engelbrecht, S.P., 1953, Geskiedenis van die Nederduitsch Hervormde Kerk van Afrika H.A.U.M - J.H. de Busy, Kaapstad.

Geyser, A.S., 1948a, 'Die kerk in die krisis', Die Hervormer XL(6), 5-7.

Geyser, A.S., 1948b, 'Die krisis in die kerk', Die Hervormer XL(7), 5-6.

Geyser, A.S., 1948c, 'Die krisis in die kerk', Die Hervormer XL(9), 6-8.

Geyser, A.S., 1948d, 'Die krisis in die kerk', Die Hervormer XL(10), 8-10.

Geyser, A.S., 1949a, 'Die krisis in die kerk', Die Hervormer XLI(2), 11-12.

Geyser, A.S., 1949b, 'Die krisis in die kerk', Die Hervormer XLI(3), 7-8.

Geyser, A.S., 1960, 'Christelike godsdiens en eiesoortige ontwikkeling. ' $n$ Beoordeling van die boek van Prof. Dr A.B. du Preez, Eiesoortige ontwikkeling tot volksdiens, H.A.U.M., Pretoria, 1959', Hervormde Teologiese Studies 16(1), 1-30.

Heyns, J.A., 1954, 'Enkele gedagtes oor die antropologie van Karl Barth', Die Gereformeerde Vaandel XXIII(3), 22-29.

Kempff, D., 1949, Die skeppingsleer by Karl Barth, H.A.U.M. - J.H. De Busy, Amsterdam.

Mostert, D., 1940, Gedenkboek van die Ossewaens op die pad van Suid-Afrika. Eeufees 1838-1938, Afrikaanse Taal- en Kultuurvereniging (S.A.S. en H.), Kaapstad.

Mulder, E.S., 1960, 'Na vyftig jaar. Ons teologiese opleiding', Die Hervormer LI(3), 9-11.

Muller, P.J., 1895, Handboek der Dogmatiek ten dienste der Ned. Hervormde Kerk, Wolters, Groningen.

Oberholzer, C.K., 1939, 'Die ideologiese betekenis van die koms van die Franse Hugenote', Die Hervormer XXVIII(55), 17-20.
Oosthuizen, A., 1949, 'Die Christelike Kerk en die naturel', Die Hervormer XLI(9), 1, 8.

Oosthuizen, A.G.J., 1950a, 'Die Christelike kerk en die naturel', Die Hervormer XLI(11), $3,8$.

Oosthuizen, A.G.J., 1950b, 'Die Christelike kerk en die naturel', Die Hervormer XLII(1), $1,8$.

Oosthuizen, A.G.J., 1960, 'Ons kerk', Die Hervormer LI(3), 18.

Pont, A.D., Voorwoord 2007, Die verhaal van ons Kerk 2, sonder uitgewer, sonder plek.

Potgieter, F.J.M., 1954, 'Die skrifbeskouing van Barth', Die Gereformeerde Vaandel XXIII(3), 31-38.

Prinsloo, J.J., 1938, 'Die Voortrekkerfeeste', Die Hervormer XXVIII(44), 15-16.

Prinsloo, J.J., 1942, '100 jaar kerk in die Transvaal', Die Hervormer XXXIII(85), 1-2.

Redaksie, 1943, 'Woord vooraf', Hervormde Teologiese Studies 1, 1-2.

Redelinghuys, M.J.J., 1960, 'Is ons sonder skuld?', Die Hervormer LI(8), 5, 6, 13, 21, 24.

Snyman, P.G.W., 1940, 'Die Barthiaanse teologie (Dialektiese teologie)', in Stoker, H.G. en Vorster, J.D. (Reds.), Koers in die Krisis II, pp. 106-153, Pro Ecclesia, Stellenbosch.

Storm, J.M.G., 1984, 'Die Voortrekkerkerk. 'n Histories-kerkregtelike studie van die Nederduitsch Hervormde Kerk 1836-1853', ongepubliseerde D. Div.-verhandeling, Universiteit van Pretoria.

Strijdom, J.J., 1931, Een studie over den samenhang en de betrekking van Barth tot Calvijn in den "Philipperbrief", H.J. Paris, Amsterdam.

Stutterheim, J.F., 1955, 'Enkele belangrike aspekte van die ekumeniese beweging', Die Hervormer XLVII(3), 8, 9.

Stutterheim, J.F., 1960, 'Calvyn en die eenheid van die kerk', Die Hervormer L(12), $6,7,19$.

Van den Berg, C.L., 1954, 'Die roeping van die Boerevolk', in Erasmus, D.F. (Red.), Almanak van die Nederduitsch Hervormde Kerk van Afrika 1954, Jaargang 48, pp. 86-95, Algemene Vergadering van die Nederduitsch Hervormde Kerk, Pretoria.

Van der Walt, S.J., 1941, Die openbaringsleer van Karl Barth, C.S.V., Stellenbosch.

Van der Westhuizen, H.M., 1939, 'Die Franse Hugenote in Suid-Afrika en hulle kulturele bydrae', Die Hervormer XXVIII(55), 15-17.

Van Selms, A., ongedateerd, 'Die gemeenskap van die Heiliges en die kleurvraagstuk', in Skrywers, ongedateer (red.), Vetraagde aksie. 'n Ekumeniese getuienis uit die Afrikaanssprekende Kerk, Die skrywers, Pretoria.

Van Zyl, F.J., 1942, 'Ons kerk en ons volk', in Engelbrecht, S.P. (Red.), Almanak van die Nederduitsch Hervormde Kerk van Afrika 1942, Jaargang 36, pp. 58-62, Algemene Vergadering van die Nederduitsch Hervormde Kerk, Pretoria.

Van Zyl, F.J., 1943, 'Die Skrifbeskouing van Karl Barth', Hervormde Teologiese Studies 1, 124-135.

Van Zyl, F.J., 1948, "n Groot Teoloog oor die Christelike doop. I', Die Hervormer $\mathrm{XL}(9), 10$.

Van Zyl, F.J., 1949a, "n Groot Teoloog oor die Christelike doop. II. Die wese van die doop', Die Hervormer XL(11), 8 .

Van Zyl, F.J., 1949b, "n Groot Teoloog oor die Christelike doop. III. Die krag van die doop', Die Hervormer XL(12), 4-5.

Van Zyl, F.J., 1949c, "n Groot Teoloog oor die Christelike doop. IV. Die sin van die doop', V. Die werking van die doop', Die Hervormer XLI(1), 6.

Van Zyl, F.J., 1949d, "n Groot Teoloog oor die Christelike doop. VI. Besware teen die kinderdoop', Die Hervormer XLI(2), 5-6.

Van Zyl, F.J., 1949e, "n Groot Teoloog oor die Christelike doop', Die Hervormer XLI(4), 5-6.

Van Zyl, J.F., 1955, 'Die kerk in die krisis van die huidige tydsgewrig', Die Hervormer XLVII(4), 14,15.

Viljoen, J.P.B., 1953, 'Die erfenis van ons vaders', Die Hervormer XLV(4), 6.

Wolmarans, H.P., 1938, 'Prof. Dr J.H. Greyvenstein', Die Hervormer XXVIII(39), 7-9.

Wolmarans, H.P., 1953, 'Die Christelike plig van die blankes teenoor die nie-blankes in Suid-Afrika', in Erasmus, D.F. (Red.), Almanak van die Nederduitsch Hervormde Kerk van Afrika 1937, Jaargang 47, pp. 100-112, Algemene Vergadering van die Nederduitsch Hervormde Kerk, Pretoria. 